\title{
Adopting Mathematics as A Desired Insrtument for The Reduction of Corruption In Nigeria
}

\author{
Joseph Ugochukwu Joseph* \\ Department of Mathematics Education, University of Agriculture, Makurdi, Nigeria \\ profjoseph4@gmail.com \\ *Corresponding Author: profjoseph4@gmail.com | Phone : +2348066351822
}

\begin{abstract}
This paper discussed that mathematics is a valuable subject, as such, it is vital in inculcating good and acceptable behaviours and values among different categories of students in Nigeria. Since corruption is not an acceptable behaviour and there is the need to avoid and prevent it in the society, it was argued that with effective mathematics teaching and learning, students will acquire the knowledge and inherent values of mathematics towards cultivating good and acceptable behaviours. This will help Nigeria to produce well-behaved citizens and to develop in a healthy manner. Some vital concepts in mathematics through which good and acceptable behaviours and values can be inculcated into students discussed in this paper include the critical roles of formulas, logic and mathematical games. The paper concluded that, besides the acquisition of knowledge, mathematics is useful in cultivating good behaviours in students for good the society. It was thereof, recommended that all mathematics teacher should be encouraged to teach the subject very well through the use of practical examples in order to make its learning simple, realistic and interesting for the students. Also, in the course of teaching, they need to give examples of how specific aspects of mathematics could be used to help in moulding the behaviours of students positively.
\end{abstract}

Keywords: Mathematics; Students' interest; Language;

\section{Introduction}

Corruption is pervasive and has the most serious effects on developing countries. Over the past few decades many studies of corruption have been carried out. These studies have mainly focused on specific characteristics such as: economic issues, legal issues, social propositions, the impact on national development, and the relationship to policy making. Theoretical considerations of corruption have emphasised econometric modelling, game theory, and similar mathematical approaches. These approaches, to be analytically tractable, aimed at addressing the entire corrupt system (Dudley, 2000). Research on corruption is vital for understanding the dynamics of corruption, and for having an efficient anti-corruption strategy. Felix, Festus, Timothy (2017) explained corruption as the misuse of public authority and has been a subject of substantial amount of empirical research over the past three decades. They further highlighted the ills of corruption as:

1. Corruption seriously harms the economy and society as a whole. Many countries around the world suffer from deep-rooted corruption that hampers economic development, undermines democracy, damages social justice and the rule of law. Corruption varies in nature and extent from one country to another, but it affects all member states. It is a complex phenomenon with economic, social, political and cultural dimensions which cannot easily be eliminated

2. Corruption has contributed immensely to the poverty and misery of a large segment of the population. Forms of corruption include - bribery, fraud, embezzlement, extortion, nepotism, favoritism. Some fundamental factors that engender corrupt practices in less developed nations are (i) the great inequality in the distribution of wealth (ii) political office as the primary means of gaining access to wealth (iii) conflict between changing moral codes (iv) the weakness of social and governmental enforcement mechanism (v) absence of a strong sense of national community. However, obsession with materialism, compulsion for a short-cut to affluence, glorification and approbation (of ill-gotten wealth) by the general public are among the reasons for the persistence of corruption in Nigeria. 
The national policy on education in Nigeria (FGN, 2004) is explicit on the need to inculcate good behaviours or character among students irrespective of their level of education towards contributing their own quota in national development. The national policy among other important issues of national interest, lay emphasis on inculcating respect for the worth and dignity of individuals; faith in the ability of man to make rational decisions; moral and spiritual principles in interpersonal and human relations; shared responsibility; promotion of physical, emotional and psychological development of all children; and the acquisition of the right type of competencies which are deemed necessary for self-reliance (FGN, 2004). These goals are to be attained using the medium of different subjects including mathematics in the school system. For this reason, the objectives of mathematics in the primary and secondary schools in Nigeria have been designed to help the students to

i. generate interest in mathematics

ii. provide solid foundation for everyday living

iii. develop computational skills

iv. foster the desire and ability to be accurate to a degree relevant to the problem at hand

v. develop precise, logical and abstract thinking

vi. develop ability to recognize problems and to solve them with related mathematical knowledge

vii. provide necessary mathematical background for further education and

viii. stimulate and encourage creativity

Other objectives are to

i. provide students with the opportunity to acquire mathematical literacy necessary to function in an information age

ii. cultivate the understanding and applications of mathematical skills and concepts which are necessary for students to thrive in the ever changing technological world

iii. develop the essential elements of problem solving and

iv. help students to solve problems involving communication, reasoning and connection (NERDC, 2007).

These objectives, besides the acquisition of genuine mathematics knowledge, are also aimed at inculcating good behaviours or character and values among students, making them run away from corruption (Thomas, 2015). However, whereas the inculcation of good behaviours or character and values among students is important for good living both in the school and the larger society, many students and youths nowadays lack good and acceptable moral values. This is evident in many crimes they most often commit in Nigeria and elsewhere in the world like cheating, arson, bribery, robbery, stealing, kidnapping, murder, gang rape, use of illegal drugs, human trafficking and thuggery.

Education sector is not left out, corruption practices tend to be rampant and robust. It could start from the point where a child enters a school to study to the point of completion of the study be it in the primary, secondary or post-secondary school. Also, it could begin from the point of fresh appointment of staff to the point of retirement in the ministry or department of education. It is usually exhibited by demand for bribes like gifts, sex, monitory inducement, acquire of illegal examination question papers, obtaining higher scores, getting better grades, getting good position, obtaining fake certificates among others. Other reasons have to do with facilitating the processing of examination results, transfers, transcripts, approval of projects and theses, allocation of funds and infrastructures, placement in a special class, staff supervision, school inspection, supervision of facilities, accreditation, procurement of learning materials and equipment, allocation of hostels, houses and special employment, and retention of staff. Also, other reasons include the need to cover up for mismanagement of funds and grants, absenteeism, private lessons, plagiarism, illegal and exorbitant fees and tuition, buying of textbooks as condition for passing examinations and paying some students to write examinations for others who are weak. One of the factors responsible for these misbehaviours is corruption. Transparency International (2014) defined corruption as the abuse of entrusted power for private gain. Also, the World Bank (1997) and UNDP (1999) defined corruption as the misuse or abuse of public office for private gain. Thomas (2015) observed that according to these authors above, corruption can come in various forms such as bribery, extortion, fraud, nepotism, graft, speed money, pilferage, theft and embezzlement. He further stated that corruption can include falsification of records, receiving kickbacks, influence peddling and campaign contributions. This is practiced in many areas of human endeavour such as education, politics, sports, transport, governance and business (Thomas, 2015).

Maduabum (2001) and Tukur and Musa (2001) posited that many weak and anxious students in Nigeria engage in these type of corrupt practices especially cheating to pass and obtain good grades in their examinations in mathematics. They most often use derogatory jargons like bullets, missiles, walkie-talkie, super-print, giraffe, computer, dubbing, body writing, expo, escort, 'laya' and ecomog to commit and perpetrate the act. Gleaning from the foregoing, therefore, the practice of corruption in education can be said 
to be multi-faceted and multidimensional in Nigeria. It is disheartening that these evil is committed and perpetrated by the collusion of many stakeholders including students, teachers, parents, tutors, guardians, supervisors, examiners, principals, invigilators, clerks, messengers, matrons, guards and cleaners (Maduabum, 2001). Little wonder this affects the educational system negatively in terms of poor teaching and learning environment, inefficient leadership and administration, poor quality service delivery and unhealthy competition. Also, it leads to low motivation for teaching and learning and low profile learning outcomes and poor quality products.

Consequently, Nigeria needs to reduce corruption in its educational system to give room for the admission of only qualified candidates, promote students based on merit only, produce qualified and wellbehaved school graduates, promote quality teaching practice, promote quality learning and school based assessment and overall, to promote best practice. It is only when this is done that Nigeria can honestly brag of using education as a veritable tool for the attainment of national development. To help prevent corruption in education, measures like, enlightenment or orientation, sanctions, campaign on values of honesty and integrity, persistence on difficult tasks and the development of good school climate and high students' efficacy (Cornelius-Ukpepi, Ndifon \& Enukoha, 2012) as well as improving the funding of education and teacher empowerment (Jimoh, 2009) have been suggested. Beyond these suggestions, there is the need for proper education of students especially those in the secondary school in Nigeria on how mathematics education can be used to shape their behaviours positively to help them to be able to avoid and prevent corruption no just in educational sector but also in every sector at large.

\section{Fighting Corruption With Mathematics}

Mathematics teaches and promotes the development of numerous critical values in the society. For example, the ideas, concepts, knowledge, skills, tasks, methods, strategies, techniques, formulas, axioms, theorems, propositions, remarks, etc in mathematics are all valuable in training students to develop good character beside knowledge acquisition. Mathematics teaches different systems of numbers and counting and calculations within the number systems. Counting enables people to understand the periods of events and to know the number of seconds, minutes, hours, days, weeks and months in a year in that order among many other things. Hence, it helps students to appreciate order and to respect and cultivate orderly behaviours. Measurement for instance enables students learn to estimate quantities in terms of weight, height, volume, capacity, length or distance and manage time and money wisely thereby expanding their thinking and reasoning skills.

Mathematics is valuable also for the fact that it is concerned with digging or exploring knowledge and inculcating critical thinking and sound reasoning among learners (Brase \& Brase, 2009). Besides this, it helps learners to develop problem solving skills (Polya, 1973; Shoenfeld, 1994); as well as communication, connections and representation skills through modelling and interpreting physical, social and mathematical phenomena (National Council of Teachers of Mathematics (NCTM), 2000). Also, mathematics is a valuable subject because it reflects and responds to vital societal values. For example, mathematics enables individual or groups of students to solve different problems and engage in various forms of calculations in construction, technology, economics and security and so on. This enable the students to learn and imbibe many inherent societal values like love, patience, perseverance, cooperation, respect, honesty and obedience. These values are useful in developing good behaviours in students to be good and patriotic citizens. Winter (2001) posited that much as mathematics is useful in developing skills and knowledge in its mechanistic nature, it serves as the means for fostering citizenship and responsibility within the society as in developing personal, spiritual, moral, social and cultural dimensions. The remaining part of the paper describes in specific terms how some mathematical concepts are useful towards developing good behaviours to help avoid and prevent corrupt tendencies among students.

\section{Using Formula To Inculcate Discipline Among Students}

In any school level in Nigeria and elsewhere in the world, students learn mathematics in the form of number and numeration, geometry, algebra, trigonometry, statistics, probability, problem solving, reasoning and proof (NERDC, 2007; National Council of Teachers of Mathematics (NCTM), 2000). At the tertiary level, the students learn higher mathematics like logic, number theory, game theory, analysis, cryptography, topology and calculus. The knowledge is useful because it is required in problem solving. In solving mathematics problems, certain rules and procedures are utilized via formulas, algorithms and mnemonics (Elliot, Kratochwill, Littlefield Cook \& Travers, 2000). It is worthy of note that the use of these formulas, rules and procedures help students approach and solve mathematics problems accurately, reasonably, orderly and honestly. Also, it helps them to learn and be obedient by following rules or directions, and learn to share their knowledge and experiences, and forge ahead collectively with commitment, patience and persistence 
and so on. This way, students learn to cultivate good behaviours (Thomas,2015).

\section{The Knowledge of Statistics And Skills In Developing Good Behaviours Among Nigeria Students}

Agbo-egwu \& Joseph (2016) states that Statistics plays a central role in scientific progress and development. Its fundamental role lies in its everyday application in most social sciences, government and business transactions, physical sciences and engineering, biological sciences and medicine, military and aerodynamic advancements and household chores. Whereas information generally is diverse, while teaching statistics, teachers are supposed to engage students in gathering data concerning food production, population growth and distribution, birth and death rates, accidents, water supply, transportation, health services and so on for decision making. The data are studied in terms of mean, mode, median, standard deviations among many other things and represented pictorially using graphs for the purpose of decision making from formulation and testing of research hypotheses using parametric and non parametric statistical tools. This enables students to learn and gain wide experience in life through critical thinking and reasoning, cooperation, collaboration and so on. This adds to the values that students need to live and enjoy good life.

\section{Mathematical Logic And The Development of Good Behaviours Among Nigeria Students}

Logic is an important form of mathematics that is useful in developing good reasoning and thinking habits among students irrespective of their level of study. Besides this, Sarkar (2003) stated that logic provides the theoretical basis for many areas of computer science like digital logic design, automata theory and computability and artificial intelligence. Logic is useful in training the mind in critical thinking and judgment. It helps to broaden the ability of students to think, reason and draw conclusions. It trains the minds of students to be reasonable, honest, sincere, obedient and humble in decision making. These are important ingredients for developing good behaviours in students for good living in the society.

\section{Geometry As A Valuable Tool In Developing Good Behaviours Among Nigeria Students}

Knowledge of geometry prepares students to be imaginative and creative in generating patterns and models thereby creating natural beauty and love. When students are creative from their knowledge of geometry for example, they can be original and also solve mathematics problems in novel ways among many other things. Woods and Barrow (1975) posit that creativity is important because it leads to the production of original products that break new ground. Thomas (2015) affirmed that when students break new grounds by creating original products, such can be sold to generate income. This will eventually make the students to be selfreliant. Creativity thus helps in fostering critical thinking, reasoning, imagination, problem solving, selfreliance, persistence, hard work, perseverance and commitment among others.

\section{Mathematical Modelling for Developing Good Behaviours Among Nigeria Students}

Mathematical modelling is concerned with the use of mathematical representation i.e. ability to use the language and tools of mathematics for communication (Schoenfeld, 1994) through verbal or non-verbal expressions like statements, graphs, matrices, equations, models and symbols like $x 2, \beta, \pi$ and $\lambda$. Also, it is the process of creating and investigating models of phenomena (Hauston, Blum, Huntley \& Neil, 1997). It unifies mathematical applications (Lassa, 1981), promotes creativity (Boaler, 1998) and transfer of knowledge, and it helps students to understand and appreciate mathematics and communicate and think about the world (Keeves, 2002). For example in thinking about the world, mathematical modelling can be used to study increase and decrease corruption level in education using model equations. This can help students to learn about corruption and also learn to avoid and prevent it to from spreading. This will help to ensure high quality educational practice less with the prevalence of high level corruption and its negative consequences on the educational system, the quality of teaching and learning and the certificates offered to students will not be valued and this can affect their employability and dignity or integrity (Thomas, 2015). Growth in corruption for example, can be illustrated for students to see through the use of corruption growth model. Consider for instance that $\mathrm{K}=\sum_{\mathrm{i}=1}^{\mathrm{n}} \mathrm{ci}$, where $\mathrm{K}(-1<k<1)$ is a constant of proportionality for sum of negative character of a person which may lead to increased or decreased corruption level (K is called mathematical effected virus constant or E-virus constant (Waykar, 2013)) and ci represents negative character, for example $\mathrm{C} 1=$ not sincere, $\mathrm{C} 2=$ unfaithful, $\mathrm{C} 3=$ dishonest, $\mathrm{C} 4=$ cheating, $\mathrm{C} 5=$ Not devotion to work or duty, C6 $=$ Not punctuality, C7 = Misbehaviours, C8 = Irregular to duty or work, C10 = Not 
attachment to work or duty, $\mathrm{C} 11=$ embezzlement, and so on. If $\mathrm{K}<0$, it means negative corruption, $\mathrm{K}=0$ means very strong free corruption and if $K>0$, it means corruption, that is the system is sick or weak. The corruption growth model is given by the relation $\frac{\mathrm{dC}}{\mathrm{dt}} \propto \mathrm{C}$ meaning $\frac{\mathrm{dC}}{\mathrm{dt}}=\mathrm{CK}$, where $\mathrm{C}=$ number of corruption, $K=$ proportionality constant, $t=$ time of growth of corruption (Waykar, 2013). Thus from $\frac{d C}{d t}=C K, \frac{d C}{C}=K d t$, by integration, loge $C=K t+C$, therefore, $C=e K t+C$ or $C=e K t . e C$. Let $e C=C 1$, then $C=C 1 e K t$. When $t=0, C=C 0$, then $\mathrm{C} 0=\mathrm{C} 1$ implying at no time or initially when $\mathrm{t}=0$, corruption is zero implying $\mathrm{K}=0$.

For instance, suppose in a new school with 1000 students, there is no corruption, then $C=0$ where $t=0$. Suppose after 10years, corruption was $1 \%$ of initial entrants, then $C=10, t=10$, the mathematical model can be obtained for increase in corruption at any time. Using $C=C 0 \mathrm{eKt}$, when $\mathrm{C}=10, \mathrm{k}=0$, i.e. $\sum_{\mathrm{i}=1}^{\mathrm{n}} \mathrm{ci}=0$, then $10=\mathrm{C} 0 \mathrm{e} 0=\mathrm{C} 0$, implying $\mathrm{C} 0=10$, consequently $\mathrm{C}=10 \mathrm{eKt}(--1)$. Suppose again that corruption level in the school doubled after 10years, then $\mathrm{t}=10, \mathrm{C}=20$, then from $(-1), 20=10 \mathrm{eKt}$ implying $20=10 \mathrm{e} 10 \mathrm{~K}$, e10K $=$ $(20 / 10)=2, \mathrm{e}(\mathrm{K}) 10=2, \mathrm{eK}=(2) 1 / 10$, therefore, $\mathrm{C}=10 \times(2) \mathrm{t} / 10$. This is the required model at time $\mathrm{t}$. Again, suppose that corruption level in the new school after 30years is required, then $t=30$, for $C=10 \times 2(t / 10)$ implies $C=10 \times 2(30 / 10)=10 \times 23=10 \times 8=80$. Thus in 30years, corruption level in the new school will be about 80 students. This figure, hypothetically, is high which can give bad name to the school. Giving this presumptuous knowledge about corruption growth, surely students can learn to work hard by thinking, communicating and enforcing many ways that will help them to avoid and prevent corruption from spreading because of the negative effects.

\section{Mathematical Games and Its Usefulness In Instilling Good Behaviour}

There are quite a number of mathematical games that can be utilized in mathematics instruction to help students especially children in the primary school in Nigeria to develop interest in mathematics and good behaviours. These include Snakes and Ladders, Ludo, Chess, Draught or Checkers and tic-tac-toe. For instance, the tic-tac-toe is a paper and pencil game for two players that make use of a $3 \times 3$ grid by placing 3 respective marks in the horizontal, diagonal or vertical rows. A player wins the game when the 3 respective marks are placed accordingly. By playing this game, students will develop observational skills, sportsmanship, honesty, hard work, sincerity, patience, confidence, self-reliance, cooperation, persistence, perseverance, love and courage to score good points and win the game. Also, when students are skilful and overzealous, and make the game and other ones and sell to their colleagues and interested people, it can help them to generate little income that will eventually make them to become self-reliant.

\section{Effect of Mathematical Problem Solving or Word Problems}

Mathematics, as it is well known, is focused mainly on problem solving. Problem solving is the act of accepting and striving to resolve challenging tasks whose solutions are not immediately known in advance (National Council of Teachers of Mathematics (NCTM), 2000). The tasks derive mainly from the society outside of the classroom involving calculations as in measurement, construction, technology, business, banking, security and so on. To succeed in problem solving, students require many problem solving skills, strategies and techniques such as ability to think, reason, plan, abstract, calculate, organize, construct and interpret information. When students are involved in problem solving in mathematics and most other subjects especially the sciences, they learn to reason well, the learn to be systematic, logical and analytic because they have to be able to analyze the problems to choose and decide on which strategies or methods are suitable to use. Also, they learn to cooperate and collaborate, share and love; to be accurate, honest, humble, respectful, patient and persistent; and to be willing, confident, self-reliant, self-satisfied and selfmotivated when they are successful. All of these virtues are useful ingredients in training students to develop good behaviours to live a good and functional life in the society.

\section{The Implication of Using Mathematics To Solve Corruption Problem In Nigeria}

a. Teachers need to teach the subject very well using practical examples and demonstrate how its values can help students to develop good behaviors. This will help in training the students to be able to avoid and prevent corrupt tendencies.

b. Mathematics teachers need to prepare students very well before any test or examination is written in mathematics.

c. Teachers should teach and emphasize the development of mathematics values among their students like critical thinking and logical reasoning, computational and problem solving skills and good communication. This will help the students to cultivate good behaviours like being honest, rational, gentle, caring, humble, loving and respectful in approaching their problems responsibly and maturely 
d. Teachers should help students to develop and sustain interest in mathematics because many of the students especially female students have negative attitudes which results in poor understanding and performance and low confidence in mathematics (Okigbo, 2007; Eshun, 2004).

e. Teachers should endeavour to use suitable teaching materials and methods like mastery learning, problem solving and cooperative learning as opposed to the use of traditional methods like lecture and expository methods since mathematics is very important and useful in cultivating good behaviours among students.

f. Mathematics teachers should set and paste some rules on good behaviours in the class for students to read and comply with during lessons, test or examination. For example, as students manifest different behaviours in class (some may be calm, anxious, noisy, etc), teachers should write the specific behaviours to tolerate and instruct students to obey otherwise they will receive punishment. This help in inculcating discipline in the students.

g. Students should be made to read and constantly remind themselves of the need to obey and keep to the rules. This will help in moulding their behaviours positively by being patient, obedient, respectful and cooperative in doing what is right, allowed or accepted. These virtues will ultimately help them to avoid and prevent corrupt tendencies.

\section{Conclusion}

In recent years, a phenomenon broadly referred to as corruption has attracted a great deal of attention. In developing countries like Nigeria, large or small, market-oriented or otherwise, governments have fallen because of accusations of corruption. The noted level of corruption would be reduced by instilling mathematical skills that would assist students think positively. It equally showed the usefulness of modelling in tackling attitudinal tendencies like corruption. This will ultimately help Nigeria to develop as a corruption-free and healthy nation.

\section{Recommendations}

All mathematics teacher should be encouraged to teach the subject very well through the use of practical examples in order to make its learning simple, realistic and interesting for the students. Also, in the course of teaching, they need to give examples of how specific aspects of mathematics could be used to help in moulding the behaviours of students positively.

\section{References}

Boaler, J. (1998). Open and Closed Mathematics Approaches: Student Experiences and Understandings. Journal for Research in Mathematics Education, 29(1), 41-62.

Cornelius-Ukpepi, B.U., Ndifon, R. A. \& Enukoha, O.I. (2012). Correlates of Examination Malpractice and Academic Performance of Primary School Students in Cross River State, Nigeria. American Journal of Social Issues \& Humanities, 2(6), 398-405.

Dudley, R. G. (2000.) The Rotten Mango: The Effect of Corruption on International Development Projectsl. Eighteenth International Conference of the System Dynamics Society "Sustainability in the Third Millennium". $\quad$ Retrieved $\quad$ February $4, \quad 2009$, from http://pws.prserv.net/RGDudley/PDF/rtmango1.pdf.

Elliot S. N., Kratochwill, T. R., Littlefield Cook, L. J., \& Travers, J. F. (2000). Educational psychology. Boston: McGraw-Hill Company Inc.

Eshun, B. A. (2004). Sex-differences in Attitude of Students towards Mathematics in Secondary Schools. Mathematics Connection, 4(1), 1-13.

Federal Government of Nigeria, (2004). Federal Government of Nigeria: National Policy on Education. Lagos: NERDC.

Felix, Y. E, Festus O, \& Timothy, A (2017). Understanding the Dynamics of Corruption Using Mathematical Modelling Approach, International Journal of Innovative Science, Engineering \& Technology, Vol. 4 Issue 8, August 2017 ISSN (Online) $2348-7968$

Hauston, S. K., Blum, W., Huntley, I. D., \& Neil, N. (1997). Teaching and learning mathematical modelling. Innovation, Investigation and Applications. Chichester: Albion Publishing Ltd.

Jimoh, B.O. (2009). Examination Malpractice in Secondary Schools in Nigeria: What sustains it? European Journal of Educational Studies, 1(3), 10 -108.

Keeves, J. (2002). Learning in Schools: A Modelling Approach. International Education Journal, 3(2), 114-125.

Lassa, P. N. (1981, August). Mathematical Modelling. Paper presented at the 19th Annual Conference of the Mathematical Association of Nigeria, Kano. 
Maduabum, M.A. (2001). Examination malpractice in Nigeria's education system: Perspectives and possibilities. In P.N. Lassa \& J.A. Aghenta (Eds.), Proceedings of the 16th Annual Congress of the Nigeria Academy of Education held in the University of Jos, 12th-16th November (pp.335-344). Jos: Fab Anieh Nigeria Limited.

National Council of Teachers of Mathematics. (2000). Curriculum and evaluation standards for school mathematics. Reston, V.A: NCTM.

Nigeria Education Resource and Development Council, (2007). Federal Ministry Of Education 9-Year Basic Education Curriculum: Mathematics for JSS1-3 and SSS 1-3. Abuja: NERDC.

Okigbo, E. C. (2007). Teaching Geometry Using Project Work. Journal of Issues on Mathematics, 10(1), 61-66.

Polya, G. (1973). How to Solve It. Princeton, NJ: Princeton University Press.

Sarkar, S.K. (2003). A Textbook of Discrete Mathematics. New Delhi: Rajendra Ravindra Printers.

Shoenfeld, A.H. (1994). What do we know about mathematics curricula? Journal of Mathematical Behavior, 13(1), 55-80.

Thomas D. B (2015). On Vital Role of Mathematics for Inculcating Good Behaviors/Values towards Curbing Corrupt Tendencies among Nigeria Students. Journal of Educational Policy and Entrepreneurial Research (JEPER) ISSN: 2408-770X (Print), ISSN: 2408-6231 (Online) Vol.2, N0.2, February 2015. Pp 44-52

Transparency International, (2012). Retrieved June 7th from www.transparency.org/gcb

Tukur, A.H. \& Musa, A.k.J. (2001). Examination malpractice among undergraduate students of university of Maiduguri: Conditions and form. In P.N. Lassa \& J.A. Aghenta (Eds.), Proceedings of the 16th Annual Congress of the Nigeria Academy of Education held in the University of Jos, 12th-16th November (pp.304-311). Jos: Fab Anieh Nigeria Limited.

UNDP, (1999). Fighting Corruption to Improve Governance. New York: United Nations Development Programme. Retrieved June 17th from www.undp.org/governance

Waykar, S.R. (2013). Mathematical Modelling: A Comparativity Mathematical Study Model Base between Corruption and Development. Journal of Mathematics, 6(2), 54-62.

Winter, J. (2001). Personal, Spiritual, Moral, Social and Cultural Issues in Teaching Mathematics. In P. Gates (Ed.), Issues in Mathematics Teaching (pp. 197-213). London: Routledge Falmer.

Woods, R.C. \& Barrow, R St. C. 1975. An Introduction to Philosophy of Education. London: University Press.

World Bank (1997). Helping countries combat corruption: The role of the world bank. Washington, DC: Poverty Reduction and Economic Management. Retrieved June 17th from www.worldbank.org 